\title{
Long-range juvenile dispersal and its implication for conservation of reintroduced swift fox Vulpes velox populations in the USA and Canada
}

\author{
David A U B B N D and Axel MoEHRENSCHLAger
}

\begin{abstract}
Dispersal is fundamental to the persistence of wild populations. Historically, swift foxes Vulpes velox of the northern Great Plains of North America have been thought to be poor dispersers. Short-grass prairie is optimal habitat for swift foxes but can be fragmented in the northern Great Plains. We wanted to assess whether wild-born, juvenile swift foxes from two proximate but distinct reintroduced populations had potential to move from one population to the other. We found five animals exhibiting long bouts of dispersal, much further than averages previously reported. One female fox traversed the long distance between the two populations and survived for at least three breeding seasons in the wild. We believe our findings are significant for conservation because they show that swift foxes are not poor dispersers and that patches of short-grass prairie previously thought to be too isolated $(>25 \mathrm{~km})$ for natural movement may be recolonized or be suitable for reintroductions of swift foxes.
\end{abstract}

Keywords Connectivity, dispersal, fragmentation, reintroduction, swift fox, Vulpes velox.

\section{Introduction}

$\mathrm{D}$ ispersal is fundamental to the genetic viability, persistence and size of populations (Harrison, 1991; Morris, 1991; Hanski, 1999). While an animal may benefit from leaving occupied habitat to seek out vacant territory, it can also encounter higher mortality rates that typically occur during dispersal (Krebs, 1978; Harris \& Trewhella, 1988). Species distribution, and hence the potential success of reintroductions, is influenced by a species' ability to disperse successfully (Krebs, 1978). Because reintroductions are, by definition, conducted where conspecifics no longer occur (IUCN, 1998), a carefully planned reintroduction will release animals in areas where resources should be relatively abundant for the first released animals. As the population increases through additional releases or population

David Ausband (Corresponding author) Wildlife Biology Program, University of Montana, 311C Forestry, Missoula, MT 59812, USA. E-mail david.ausband@mso.umt.edu

Axel Moehrenschlager Centre for Conservation Research, Calgary Zoological Society, Calgary, Canada.

Received 13 September 2007. Revision requested 30 November 2007. Accepted 7 January 2008. growth, the habitat may become saturated and pressures to disperse may increase. Achieving connectivity for reintroduced populations of carnivores is difficult in fragmented landscapes because home range requirements are generally large and suboptimal habitat matrices between populations can serve as high mortality sink zones (Moehrenschlager \& Somers, 2004).

Patches of optimal short-grass prairie habitat for swift foxes Vulpes velox are disjunct throughout the northern plains as a result of extensive cultivation, and populations of swift foxes may be isolated from one another because of an inability to cross a harsh cultivated matrix (Saunders et al., 1991). Furthermore, population isolation may lead to inbreeding depression thereby affecting the long-term persistence of disjunct populations (Keller \& Waller, 2002).

The ability of swift foxes to disperse long distances is thought to be less than for larger canids (Mercure et al., 1993) and, in part because of limited gene flow, they have retained distinct species status from kit foxes Vulpes macrotis with which they interbreed in areas of New Mexico (Mercure et al., 1993). Reported dispersal distances for 48 juvenile kit foxes in California averaged only $7.8 \pm$ SE $1.1 \mathrm{~km}$ (Koopman et al., 2000) and eight juvenile swift foxes in Colorado moved just $12.6 \pm \mathrm{SE} 3.2 \mathrm{~km}$ from their last known den to their first discovered den after movement ceased or death occurred (Schauster et al., 2002).

Swift foxes are listed as an Endangered Species in Canada and reintroduction efforts began in 1983. Swift foxes are not listed under the Endangered Species Act in the USA but they are a Species of Concern in Montana and are of particular cultural significance to the Blackfeet Tribe in Montana, who began reintroducing swift foxes to Reservation lands in 1998. Recent studies and surveys have indicated swift fox reintroductions in both Canada and on the Blackfeet Reservation in Montana were successful (Moehrenschlager \& Moehrenschlager, 2001; Ausband \& Foresman, 2007a), with populations growing and expanding their distributions, although we believe there is still some vacant suitable habitat within both study areas. Swift fox densities near the Canadian release sites are high (Moehrenschlager \& Moehrenschlager, 2006) and although density estimation was not a focus of research on the Blackfeet Reservation, relative density of swift foxes near and around ( $\leq 20 \mathrm{~km}$ radius) the original release site was high (D. Ausband, unpubl. data). Genetic viability and persistence of these two populations would be enhanced through an interchange of individuals. 
Therefore, we wanted to assess potential dispersal of juvenile swift foxes between the two proximate but distinct reintroduced swift fox populations that collectively span the borders of Alberta and Saskatchewan in Canada and Montana in the USA. At their nearest point, foxes within these two populations are separated by mostly cropland spanning c. $200 \mathrm{~km}$ (Fig. 1).

\section{Study area}

The Blackfeet Reservation, in northern Montana, USA encompasses 607,000 ha of largely short-grass prairie habitat on the eastern flank of the Rocky Mountains. Annual precipitation averages $31.8 \mathrm{~cm}$ and temperatures range from $-40^{\circ} \mathrm{C}$ in January to $41^{\circ} \mathrm{C}$ in July. The Canadian swift fox population inhabits c. $12,000 \mathrm{~km}^{2}$ of short-grass prairie in southern Alberta and Saskatchewan. Annual temperature and precipitation are similar to that of the Blackfeet Reservation.

\section{Methods}

We live-trapped juvenile swift foxes at different times over 1995-2006 in two reintroduced populations (Fig. 1) as part of research on each individual population. Foxes were captured in box traps (Ausband \& Foresman, 2007a; Moehrenschlager et al., 2007) baited with wet cat food, sardine oil or butcher scraps. Traps were lined with wood and wire mesh to decrease the chance of injury to trapped foxes if they attempted to chew on the cage to escape (Moehrenschlager et al., 2003). Foxes caught on the Blackfeet Reservation were fitted with $48 \mathrm{~g}$ high frequency radiocollars, including mortality sensors and antenna lengths of $15-20 \mathrm{~cm}$ (Advanced Telemetry Systems, Isanti, USA), injected with transponders (AVID ID Systems, Norco, USA) between their shoulder blades, and ear-tagged or tattooed depending on location of capture and year of study. Capture and handling of animals in Montana was approved under the IACUC protocol number 036-04KFDBS-043005, and Canadian captures were

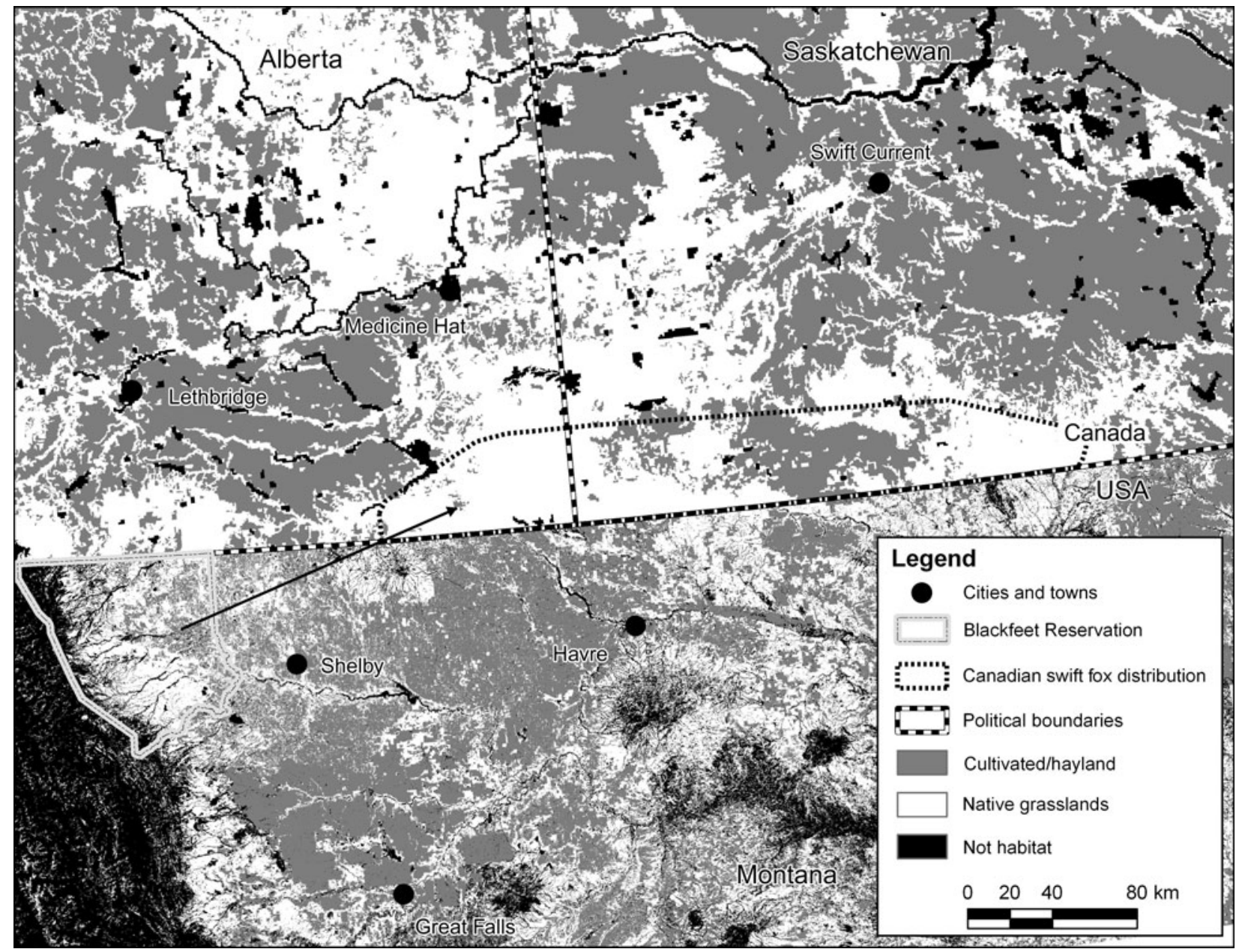

FIG. 1 Map showing grassland habitat and cropland non-habitat for swift foxes along the Canada-USA border. The straight-line arrow denotes, in simplified form, the longest movement detected of a female that dispersed from the Blackfeet Reservation, USA, to the Canadian population. 
approved by individual permits from Environment Canada, Alberta Fish \& Wildlife, and Saskatchewan Environment and Resource Management.

During 1995-1998 swift foxes in Canada were captured in similar box traps, manually restrained, and handled by two field workers who conducted parasite counts, canine measurements, and body condition assessments. Foxes were sexed, ear-tattooed and treated with Ivermectin (Merial Limited, Iselin, USA; $0.2 \mathrm{mg} \mathrm{kg}^{-1}$ ) to combat parasite infestation, and radio-collared. Vaccinations against canine distemper, adenovirus, parainfluenza, parvovirus, and leptospirosis were administered using Duramune (Wyeth-Ayerst, St. Davids, USA; $10 \mathrm{mg} \mathrm{ml}^{-1}$ ), and Imrab (Wyeth-Ayerst, St. Davids, USA; $10 \mathrm{mg} \mathrm{ml}^{-1}$ ) provided vaccination against rabies. Radio-collars weighed $48 \mathrm{~g}$, had a mortality sensor and antenna lengths of $15-20 \mathrm{~cm}$. In 2000-2001 and 2005-2006, as part of a 5-year census effort, swift foxes in Canada were again captured in box traps. Canadian traps were lined completely with hardboard that was custom made with small holes; the floor, ceiling, and sides were lined with hardboard while the door and back were lined with plexiglass so that captured foxes could be seen easily (Cotterill, 1997; Moehrenschlager \& Moehrenschlager, 2001).

Catch-and-release trapping was conducted at night (the fox activity period) to avoid heat-stress and to prevent disturbance by people. Traps were generally set at $18.00-$ 20.00, checked at 24.00-02.00, and closed following a second check at 06.00-08.00. Trapping was not conducted at temperatures colder than $-20^{\circ} \mathrm{C}$ or when snow, rain or wind conditions were potentially hazardous to captured foxes (Moehrenschlager \& Moehrenschlager, 2001). Foxes were coaxed into a denim handling bag that was placed over the end of the box trap. Every team alternated between four handling bags, which were washed frequently to reduce the transmission of fleas between foxes. Foxes were handled by both field workers of respective trapping teams. The first team member positioned the animal on his/her lap to shelter it from the wind, one hand restrained the head and covered the eyes, and the second hand restrained the body. The second field worker sexed and aged the fox, conducted parasite counts, scored body condition through palpation on a standardized index ranging from 1 (poor) to 5 (excellent), collected a hair sample for genetic analyses, checked for injuries, and tattooed the ear for identification. Foxes were uniquely marked with tattoo dye so that recaptured individuals could be easily identified.

We calculated dispersal as the straight-line distance moved between the location where a juvenile was captured in its natal range to where it was located when exploratory movement ceased or death occurred. Animals that remained within $2 \mathrm{~km}$ of their natal range were not considered dispersers. Some juveniles exhibited two bouts of dispersal (Ausband \& Foresman, 2007b), ceasing exploratory movement for $\geq 30$ days only to resume exploratory movements again. We summed these straight-line distances to provide a total distance dispersed.

\section{Results}

Over 1995-1998 43 juvenile swift foxes were captured and radiocollared in the Canadian reintroduced swift fox population. In the Canadian transboundary 5-year census we captured 149 and 196 swift foxes in 2000-2001 and 2005-2006, respectively, in Canada and contiguous areas of Montana. None of these foxes were recovered on the Blackfeet Reservation and males and females dispersed relatively short distances, $12.4 \pm \mathrm{SE} 4.3 \mathrm{~km}$ and $10.6 \pm \mathrm{SE}$ $4.7 \mathrm{~km}$ respectively, from natal dens. Over 2003-2005 36 juvenile foxes were radiocollared and ear-tagged or pit-tagged on the Blackfeet Reservation and one of these was recovered during trapping efforts in south-eastern Alberta on 6 November 2005 .

On the Blackfeet Reservation five radiocollared wildborn juveniles, three males and two females, moved relatively long total distances during 2003-2005. We report only long distance dispersal movements $(>50 \mathrm{~km}$ total) here because general facets of dispersal for this population are presented in Ausband \& Foresman (2007b). Minimum distance dispersed averaged $50.5 \pm$ SE $3.6 \mathrm{~km}$ for four of the juveniles. A fifth juvenile female fox travelled much further $(191 \mathrm{~km})$ and, 3 years after initial capture on the Blackfeet Reservation, was live-trapped as part of a monitoring effort in the Canadian population (Table 1). This fox had shed its radiocollar shortly after capture ( $>7$ days) and although we lost contact with her on the Blackfeet Reservation we were able to identify her from ear tags when she was captured in Canada. This female was caught $1 \mathrm{~km}$ and $3 \mathrm{~km}$ away from swift fox males in February 2006, 1 month before the breeding season.

\section{Discussion}

Wild-born juvenile swift foxes appear capable of relatively long bouts of dispersal, and further than previously thought.

TABLE 1 Straight-line distance moved by five wild-born, juvenile swift foxes on the Blackfeet Indian Reservation, Montana, USA, during 2003-2005. Foxes born in April/May were considered juveniles from 1 September to 1 June of the year following birth.

\begin{tabular}{llc}
\hline Sex & $\begin{array}{l}\text { Month dispersal } \\
\text { initiated }\end{array}$ & $\begin{array}{l}\text { Straight-line distance } \\
\text { moved }(\mathrm{km})\end{array}$ \\
\hline Female & Sep. & 55.8 \\
Female & Feb. & 190.9 \\
Male & Sep. & 57.4 \\
Male & Oct. & 43.1 \\
Male & Oct. & 45.6 \\
\hline
\end{tabular}


In one instance a female swift fox was able to traverse the long distance between the two reintroduced populations, potentially providing genetic interchange between these seemingly disjunct populations.

With the exception of a juvenile kit fox that moved $64 \mathrm{~km}$ in Nevada (O'Neal et al., 1987), the long-distance dispersal events recorded here exceed natal kit or swift fox dispersal movements recorded to date (Moehrenschlager et al., 2004; Ausband \& Foresman, 2007b). The lack of reported long-distance dispersal movements in contiguous swift or kit fox populations may be due to a relative abundance of prey or mates. The reintroduced northern populations, which are on the periphery of the species' historic range, may be more resource limited; reintroduced swift foxes in Canada have larger home range requirements than conspecifics in southern populations (Moehrenschlager et al., 2007). Moreover, the amount of suitable habitat for reintroduced populations may be limited and foxes may be more likely to disperse over large distances as populations become saturated, although Trewhella et al. (1988) found the opposite to be true for a large sample of urban red foxes Vulpes vulpes in Bristol, UK. Swift fox releases have shown that survival and reproduction decrease with risky longrange movements (Moehrenschlager \& Macdonald, 2003) and it would seem logical that the further an animal disperses from its core range the less likely it will be to find a mate. However, successful dispersers may enhance the ability of the USA and Canadian populations to be genetically viable over time. Even a small amount of gene flow between two populations can enhance heterozygosity of individuals (Mills \& Allendorf, 1996), although the actual number of real migrants required may be more than oneper-generation (Wang, 2004)

Historically, swift fox populations reintroduced in Canada and in Montana have been managed as separate entities. Our evidence of potential long-distance dispersal movements illustrates that collective recovery of these populations is possible in a metapopulation context. While movement of a swift fox was recorded from the Blackfeet Reservation into Canada we did not record movement in the opposite direction. Movement south from Canada could have occurred but went undetected because the research on the Blackfeet Reservation did not focus on the northern portion of the Reservation that borders Canada.

This research shows that swift foxes are not necessarily poor dispersers and that patches of short-grass prairie, previously thought too isolated for natural movement or colonization, should be conserved to enhance swift fox population connectivity and range. Specifically, entities currently reintroducing or recovering swift foxes (most western plains states in the USA, and Alberta and Saskatchewan, Canada) should not dismiss patches of short-grass prairie habitat that are $>25 \mathrm{~km}$ from the initial release site or recovery core. These seemingly isolated areas can be colonized by dispersing swift foxes and post-release monitoring programmes should also include survey efforts in these disjunct patches.

\section{Acknowledgements}

Field work in Canada was funded by Alberta Conservation Association, Alberta Fish \& Wildlife, Calgary Zoo, Canadian Wildlife Service, Fairmont Palliser hotel, Husky Energy, Montana Fish Wildlife \& Parks, Parks Canada, Prairie Farm Rehabilitation Agency, Saskatchewan Environment and Resource Management, Wildlife Preservation Canada, and WWF-US. Field work in the Blackfeet Reservation was funded through Defenders of Wildlife, Sigma Xi, Blackfeet Tribe and SWG. Special thanks to Cynthia Moehrenschlager, Ryan Rauscher, Pat Fargey, Brian Giddings, Elizabeth Ausband, Minette Johnson, Dan Carney, Adrian Costel and field crews who worked long hours to collect data. We appreciate comments from two anonymous reviewers that helped strengthen this article.

\section{References}

A UsBand, D.E. \& Foresman, K.R. (2007a) Swift fox reintroductions on the Blackfeet Indian Reservation, Montana, USA. Biological Conservation, 136, 423-430.

Ausband, D.E. \& Foresman, K.R. (2007b) Dispersal, survival, and reproduction of wild-born yearling swift foxes in a reintroduced population. Canadian Journal of Zoology, 85, 185-189.

Cot terill, S.E. (1997) Population Census of Swift Fox (Vulpes velox) in Canada: Winter 1996-1997. Report prepared for the Swift Fox National Recovery Team. Alberta Environmental Protection, Natural Resources Service, Wildlife Management Division, Alberta, Canada.

Hanski, I. (1999) Metapopulation Ecology. Oxford University Press, Oxford, UK.

Harris, S. \& Trewhella, J. (1988) An analysis of some of the factors affecting dispersal in an urban fox (Vulpes vulpes) population. Journal of Applied Ecology, 25, 409-422.

HARRISON, S. (1991) Local extinction in a metapopulation context: an empirical evaluation. Journal of Zoology, 42, 73-88.

IUCN (1998) IUCN Guidelines for Re-introductions. IUCN/SSC Re-introduction Specialist Group. IUCN, Gland, Switzerland, and Cambridge, UK.

Keller, L.F. \& Waller, D.M. (2002) Inbreeding effects in wild populations. Trends in Ecology \& Evolution, 117, 230-241.

Koopman, M.E., Cypher, B.L. \& Scrivner, J.H. (200o) Dispersal patterns of San Joaquin kit foxes (Vulpes macrotis mutica). Journal of Mammalogy, 81, 213-222.

KreBs, C.J. (1978) Ecology: The Experimental Analysis of Distribution and Abundance. Harper \& Row, New York, USA.

Mercure, A., Ralls, K., Koepfli, K.P. \& Wayne, R.K. (1993) Genetic subdivisions among small canids: mitochondrial DNA differentiation of swift, kit, and arctic foxes. Evolution, 47, $1313-1328$.

Mills, L.S. \& Allendorf, F.W. (1996) The one-migrant-pergeneration rule in conservation and management. Conservation Biology, 10, 1509-1518.

Moehrenschlager, A., Cypher, B.L., Ralls, K., Sovada, M.A. \& List, R. (2004) Comparative ecology and conservation 
priorities of swift and kit foxes. In Biology and Conservation of Wild Canids (eds D.W. Macdonald \& C. Sillero-Zubiri), pp. 185-198. Oxford University Press, Oxford, UK.

Moehrenschlager, A., List, R. \& Macdonald, D.W. (2007) Escaping interspecific killing: Mexican kit foxes survive while coyotes and golden eagles kill Canadian swift foxes. Journal of Mammalogy, 88, 1029-1039.

Moenrenschlager, A. \& Macdonald, D.W. (2003) Movement and survival parameters of translocated and resident swift foxes (Vulpes velox). Animal Conservation, 6, 199-206.

Moehrenschlager, A., Macdonald, D.W. \& MoehrenschlAGER, C. (2003) Reducing capture-related injuries and radiocollaring effects on swift foxes. In The Swift Fox: Ecology and Conservation of Swift Foxes in a Changing World (eds L.N. Carbyn \& M.A. Sovada), pp. 107-113. Canadian Plains Research Center, University of Regina, Regina, Canada.

Moenrenschlager, A. \& Moenrenschlager, C. (2001) Census of Swift Fox (Vulpes velox) in Canada and Northern Montana: 2000-2001. Alberta Species at Risk Report No. 24, Alberta Sustainable Resource Development, Fish and Wildlife Division, Edmonton, Canada.

Moenrenschlager, A. \& Moehrenschlager, C. (2006) Population Census of Reintroduced Swift Foxes (Vulpes velox) in Canada and Northern Montana 2005/2006. Centre for Conservation Research, Calgary Zoo, Calgary, Canada.

Moenrenschlager, A. \& Somers, M. (2004) Canid reintroductions and metapopulation management. In Canids: Foxes, Wolves, Jackals and Dogs. Status Survey and Conservation Action Plan (eds C. Sillero-Zubiri, M. Hoffmann \& D.W. Macdonald), pp. 289-297. IUCN/SSC Canid Specialist Group, Gland, Switzerland, and Cambridge, UK.
Morris, D.W. (1991) On the evolutionary stability of dispersal to sink habitats. The American Naturalist, 137, 907-911.

O'Neal, G.T., Flinders, J.T. \& Clary, W.P. (1987) Behavioral ecology of the Nevada kit fox (Vulpes macrotis nevadensis) on a managed desert rangeland. In Current Mammalogy (ed. H.H. Genoways), pp. 443-481. Plenum Press, New York, USA.

Saunders, D.A., Hobbs, R.J. \& Margules, C.R. (1991) Biological consequences of ecosystem fragmentation: a review. Conservation Biology, 5, 18-32.

Schauster, E.R., Gese, E.M. \& Kitchen, A.M. (2002) Population ecology of swift foxes (Vulpes velox) in south-eastern Colorado. Canadian Journal of Zoology, 80, 307-319.

Trewhella, W.J., Harris, S. \& McAllister, F.E. (1988) Dispersal distance, home range size and population density in the red fox (Vulpes vulpes): a quantitative analysis. Journal of Applied Ecology, 25, 423-434.

WAnG, J. (2004) Application of the one-migrant-per-generation rule to conservation and management. Conservation Biology, 18, $332-343$.

\section{Biographical sketches}

DAVID E. AUSBAND has been participating in canid conservation in the Northern Rockies, USA, for the last 8 years. He is particularly interested in developing novel methods for long-term monitoring of wide-ranging carnivore populations. Axel Moehrenschlager is a member of the IUCN Canid and Reintroduction Specialist Groups. His Centre for Conservation Research at the Calgary Zoo conducts fundamentally significant and directly applicable research regarding reintroductions of threatened mammals, birds and amphibians. 